\title{
Nutritional and Gut Microbial Analyses of Adult Male Cockroaches (Periplaneta americana) (Dictyoptera, Blattodea) from Three Locations in Abeokuta, Nigeria
}

\author{
Kehinde Olutoyin Ademolu, Oluwatosin Yetunde Mustapha \& Adewunmi Babatunde Idowu
}

\begin{abstract}
Summary: Cockroaches are cosmopolitan insects and are found in different parts of the house. There has been an increase call for their inclusion in the diet of both man and livestock. However, their nutritional value and gut microbial load based on different locations had received little attention in literature. This study aimed at investigating nutritive value and the microbial load in the gut of male cockroaches found in different locations (dumpsite, kitchen and toilet). Thirty (30) adult male cockroaches (Periplaneta americana), ten (10) from each location were used. The gut was taken out for microbial analysis and the other parts of the cockroaches were arranged for proximate composition, minerals and vitamins analysis using standard methods. Data analysis was done using one-way analysis of variance (ANOVA) and Student Newman Kuel was used for mean separation of significant means. The gut microbial analysis from the three locations revealed that bacterial and fungal counts $(2.00 \times 105 \mathrm{cfu} / \mathrm{ml}, 9.00 \times 105 \mathrm{cfu} / \mathrm{ml}$ respectively $)$ in cockroaches from the dumpsite were significantly higher $(\mathrm{p}<0.05)$ than other sites. Cockroaches collected from the kitchen had highest $\mathrm{Ca} 2+$ and $\mathrm{Mg} 2+$ concentrations while cockroaches from the dumpsite had the least. Proximate composition showed that cockroaches from the kitchen had significantly higher $(\mathrm{p}<0.05)$ protein, ash, fat and carbohydrate content than other locations. This study showed that location affects the nutritional and microbial content of cockroaches.
\end{abstract}

Key words: cockroaches, nutritional value, location, microorganisms

\section{Introduction}

Cockroaches are considered one of the most adaptable insect groups ever in human history (ETIM et al. 2013). Of the over 4,000 known species of cockroaches, only a dozen can be considered as pests. These include the American Cockroach; Periplaneta americana (about 30 millimeters long), the German cockroach, Blatella germinica (about 14 millimeters long), the Brown banded cockroach Supella longipalpa (about 14 millimeters long) and the oriental cockroach, Blatta orientalis (about 14 millimeters long). Reports have shown that the American cockroach, P. americana and the German cockroach, B. germanica are the most common cockroaches infesting buildings worldwide (UNEKE 2007, OMUdU and EYUMAH 2008).

Cockroaches live in groups and are attracted to humidity, warmth and darkness and are common in toilets, bathrooms, kitchens and dining and bedrooms. The American cockroach (Periplaneta americana) is the largest. They can survive up to two years, much longer than other cockroaches' types. Cockroaches have dirty habits with an ability to spoil food, transfer pathogens, cause allergic reactions and psychological distress (BRENNER 1995). Cockroaches breed and forage in sewer systems, garbage bins, and latrines (MPUCHANE et al. 2006). They are nocturnal in habit and transmit pathogens rapidly at night (FISCHER et al. 2003). They frequently feed on human faeces, garbage and sewage; therefore they have copious opportunity to disseminate pathogenic agents (UCKAY et al. 2009). Their attraction to human and animal faeces, rotting food, secretions from corpses, sputum, pus, and the like gives them a well-earned "disgust factor" among the general public. These moist, organic habitats contain staggering amounts of bacteria, protozoa, amoebae, fungi, and other microbial material (WILLIAM et al. 2011).

It has been particularly difficult to determine specific nutritional values for cockroaches, partly because of the presence of microbial symbiotes (bacteroids) in specialized cells (mycetocytes) in the fat body. Elimination of symbiotes from $P$. americana by antibiotic treatment results in poor growth and diminished reproductive capacity (RICHARDS and BROOKS 1958).

YI et al (2013) reported insect protein quality to be higher than soyabean and lower than casein proteins. BARRoso et al. (2014) stated that amino acid profile of some Diptera is superior to soyabean meal. Evaluation of the nutritive value of cockroaches become important as the insects could form a base for new feed product of considerable nutritive value. Similarly the nutritional value changes according to the preparation and processing before consumption 
(drying, cooking, frying etc.) (HUIS-VAN et al. 2013). According to PAYNE et al (2016) insect's nutritional composition showed high diversity between species. Due to the limited information, this study investigates the nutritional value of cockroaches based on their locations.

\section{Materials and methods}

\section{Experimental Site}

This study was carried out in the laboratory of the Department of Pure and Applied Zoology, Federal University of Agriculture, Abeokuta, Ogun State, Nigeria.

\section{Experimental Procedures}

Adult cockroaches were captured (mostly at night time and early morning) from different locations in hostels at Camp Area of Abeokuta (kitchens, toilets and dumpsites) by hand picking method using sterile gloves and transferred to perforated containers for access to air. These containers were directly transferred to laboratory for further process. On the arrival of the cockroaches at the laboratory, ten male cockroaches were put into an envelope and kept in the freezer for 10 minutes to make them immobile. After 10 minutes, each cockroach was weighed using electric weighing scale and weight was calculated. Other cockroach samples (50) were arranged for chemical analysis.

(a) Morphometrics: The morphometric studies of each cockroach were also carried out with concise reading taken. The measurements of the following body parts were carried out using calibrated ruler: body length,head, thoracic, abdomen, wings length, prothoracic leg, mesothoracic leg and metathoracic leg.Each cockroach samples was dissected at a time to avoid mix up during microbial analysis of the gut content. The gut measurement (fore gut, mid gut and hind gut), each cockroach was dissected as the whole gut was removed carefully with the aid of forceps.

(b) Proximate Analysis: the moisture, ash, crude fat, crude fibre and crude protein, and carbohydrate content of the experimental cockroaches were determined by A.O.A.C. (1990) method.

(c) Mineral Analysis: Mineral $\left(\mathrm{Na}^{+}, \mathrm{K}^{+}, \mathrm{Ca}^{2+}, \mathrm{Fe}\right.$, $\mathrm{Mg}^{2+}$ and $\left.\mathrm{Cl}^{-}\right)$composition of the cockroaches from the three locations were determined using Atomic Absorption Spectrophotometry (AAS).

(d) Vitamins Composition: Vitamin (Vitamins A, $\mathrm{B}_{2}$ and $\mathrm{C}$ ) composition of the cockroach samples were determined following methods of A.O.A.C. (1990).

All chemical analyses were done in triplicates.

(e) Microbial Analysis of the gut: Ten cockroaches (from each location) were dissected following protocols describe by ADEMOLU and IDOWU (2011). The whole gut was removed and the content emptied into sterile labeled petri dishes and kept in refrigerator for further microbial examination. The bacteria enumeration and identification were done by method of SNEATH et al. (1986). Identification of fungi was done by Bernett and Hunter (1972) techniques.

\section{Statistical Analysis}

Data collected were analyzed using One-way Analysis of Variance (ANOVA). Separation of significant means was done using the StudentNewman-Keuls (SNK).

\section{Results}

The results of the morphometrics of cockroaches from three different locations are presented in Table 1. There was no significant difference $(p>0.05)$ in the measurement of head, thorax and abdomen of cockroaches from the three locations. The body length of the cockroaches from the three locations showed no significant difference $(p>0.05)$ as well. The metathoracic legs of cockroaches from the dumpsite $(3.96 \pm 0.45 \mathrm{~cm})$ had the lowest measurement compared to the toilet, which had the highest measurement of $(5.00 \pm 0.25 \mathrm{~cm})$. The body length and mesothoracic legs also followed the same trend. The body weight of cockroaches from the dumpsite was significantly higher $(\mathrm{p}<0.05)$ than other locations.

Table 2 shows the proximate composition of cockroaches from different locations in Abeokuta. The moisture content of cockroaches in all three locations, and there was significant difference $(\mathrm{p}<0.05)$ among cockroaches from the dumpsite to the cockroaches found in the toilet and kitchen. The cockroaches found in the dumpsite have the highest value of $(69.91 \pm 1.29 \mathrm{acm})$ while kitchen has the lowest value of $(57.62 \pm 2.83 \mathrm{bcm})$. Fat content, crude protein content and carbohydrate of cockroaches from the kitchen showed significant difference $(p<0.05)$ from the other two locations.

Mineral analysis of cockroaches from all three locations shows the presence of $\mathrm{Na}+, \mathrm{K}+, \mathrm{Ca} 2+$,

$\mathrm{Fe}, \mathrm{Mg} 2+$ and $\mathrm{Cl}-$ (Table 3). Cockroaches collected from the kitchen had the highest $\mathrm{Ca} 2+, \mathrm{g} 2+$ concentrations, while cockroaches from the dumpsite had the least. It can also be seen that $\mathrm{Fe} 2+$ and $\mathrm{Cl}$ - are the least minerals present in all three locations.

Results showed the presence of vitamins $\mathrm{A}, \mathrm{B}_{2}$ and $\mathrm{C}$ in the cockroaches from the three locations. There was significant difference $(p<0.05)$ in the composition of vitamin C.

Cockroaches in the kitchen have the highest vitamins while dumpsite has the least vitamins.

Vitamin A is least of vitamins amongst the cockroaches from all the three locations (Table 4).

Microbial analysis of the gut regions of $P$. americana is shown in Figure 1. It shows that fungi growth is significantly higher than bacterial growth in the gut of cockroaches picked from all the three locations. The result of microbial analysis conducted on the gut of cockroaches from the three locations revealed that bacterial and fungal counts $(2.00 \times 105 \mathrm{cfu} / \mathrm{ml}, 9.00 \times 105 \mathrm{cfu} / \mathrm{ml}$ respectively $)$ in 


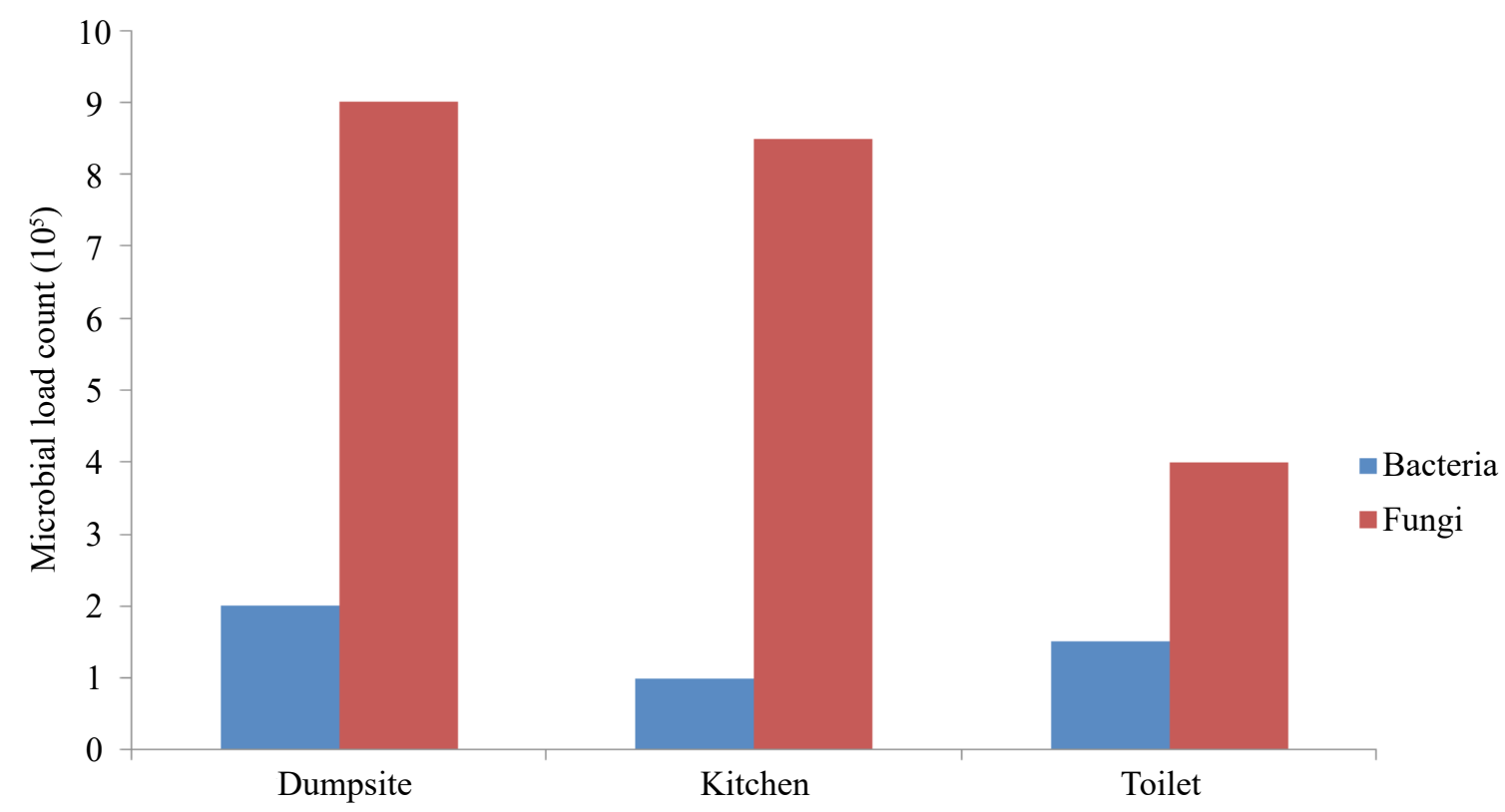

Sample sites

Fig. 1. Gut bacterial and fungi $(\mathrm{cfu} / \mathrm{ml})$ of adult male cockroaches (Periplaneta americana) from the three locations

cockroaches from the dumpsite were significantly higher $(\mathrm{p}<0.05)$ than other sites.

Microflora isolated from the gut of the cockroaches from all the three location is presented in Table 5. The bacterial isolated from the gut of male cockroaches were Staphylococcus aureus, Bacillus subtilis and Enterobacter species. Bacillus subtils appeared in all three locations.

Isolated fungi from the gut of male cockroaches were Curvularia species, Geotricum species, yeast, Trichophton species, and Aspergillus candidus. Curvularia species appeared in both dumpsite and kitchen while Geotricum species appeared in both dumpsite and toilet, and Aspergillus candidus appeared at both kitchen and toilet.

\section{Discussion}

In all of the examined cockroaches high concentrations of fat, ash, protein as well as carbohydrate were found in cockroaches from the kitchen, this is due to their diet and the richness in their food. This means that the adult $P$. americana cockroaches used in our study are a similar source of protein and lipids like other species of cockroaches (OonincX and Dierenfeld 2012, Bosch et al. 2014). This nutrient composition of these cockroaches makes them good sources of nutrient supply to humans and could make up animals feed.

It is reasonable to assume that sodium, potassium, magnesium, calcium, iron and chloride are essential minerals for the functions of insects. Which agrees with FINKE (2002) that stated that insects are also a relatively good source of minerals, such as phosphorus, magnesium, sodium or chloride, and trace elements. Mineral content of $\mathrm{Ca} 2+$ was high which does not agree with (BARKER and DIERENFELD 1998, Finke 2002, Oonincx and Dierenfeld 2012). Calcium concentration was highest in the kitchen and this could be due to their diet, they get to feed on food left over like fish, beans, cheese which are rich sources of calcium. Dumpsite appeared to have the lowest calcium concentration amongst the three locations and this could be due to their diet as well. Presence of calcium helps in wound healing. PeArson and GILLET (1999) reported that calcium is the most abundant mineral element in the animal body and an important constituent of the skeleton and teeth, where around $99 \%$ of the total calcium in the body is body is found. Subsequently, $P$. americana extract has been widely used in China to heal severe ulcers and burns. It is administered intravenously and orally or directly applied on the wounds topically (BROwN et al. 2004, JEONG et al. 2004).

This study shows that fungal load is higher than bacteria, and there are high microbes in the gut of cockroaches, this means better utilization of food. The microbes were significantly higher in cockroaches from dumpsite compared to the other two locations. This is possibly due to moist environment which consists of decaying matter, household dirts and other particles unlike toilet which is usually dry and consist of debris and the kitchen which consists of food spills and left over. The feeding of cockroaches on dumpsites also enhance the growth of fungi due to the fact that they thrive in moist environment. They also aid in the digestion of food.

There was predominance of Bacillus sp. in the cockroaches from all the three locations. The distribution of bacterial organisms was not so different from the report of TATFENG et al. (2005) except that, in this work, Bacillus sp. was the most frequently seen 
N Table 1. Morphometric of adult male cockroaches (Periplaneta americana) from three locations in Abeokuta.*

\begin{tabular}{|c|c|c|c|c|c|c|c|c|c|c|}
\hline Location & $\begin{array}{c}\text { Average } \\
\text { Body weight (g) }\end{array}$ & $\begin{array}{c}\text { Body } \\
\text { Length }(\mathrm{cm})\end{array}$ & $\begin{array}{l}\text { Head } \\
(\mathrm{cm})\end{array}$ & $\begin{array}{l}\text { Thorax } \\
(\mathrm{cm})\end{array}$ & $\begin{array}{l}\text { Abdomen } \\
(\mathrm{cm})\end{array}$ & $\begin{array}{l}\text { Pro thoracic } \\
\text { leg }(\mathrm{cm})\end{array}$ & $\begin{array}{l}\text { Meso thoracic } \\
\text { leg }(\mathrm{cm})\end{array}$ & $\begin{array}{l}\text { Meta thoracic } \\
\text { leg }(\mathrm{cm})\end{array}$ & $\begin{array}{c}\text { Inner wing } \\
(\mathrm{cm})\end{array}$ & $\begin{array}{l}\text { Outer wing } \\
(\mathrm{cm})\end{array}$ \\
\hline Dumpsite & 1.02 & $3.42 \pm 0.21^{\mathrm{a}}$ & $0.54 \pm 0.05^{\mathrm{a}}$ & $0.86 \pm 0.05^{\mathrm{a}}$ & $1.95 \pm 0.34^{\mathrm{a}}$ & $2.48 \pm 0.36^{\mathrm{a}}$ & $3.32 \pm 0.57^{\mathrm{a}}$ & $3.96 \pm 0.45^{\mathrm{b}}$ & $2.54 \pm 0.11^{\mathrm{a}}$ & $2.92 \pm 013^{\mathrm{b}}$ \\
\hline Kitchen & 0.62 & $3.76 \pm 0.21^{\mathrm{a}}$ & $0.62 \pm 0.11^{\mathrm{a}}$ & $1.20 \pm 0.04^{\mathrm{b}}$ & $2.30 \pm 0.09^{\mathrm{a}}$ & $2.38 \pm 0.31^{\mathrm{a}}$ & $3.52 \pm 0.08^{\mathrm{a}}$ & $4.80 \pm 0.23^{\mathrm{a}}$ & $2.26 \pm 0.13^{\mathrm{a}}$ & $2.62 \pm 0.08^{b}$ \\
\hline Toilet & 0.98 & $3.83 \pm 0.26^{\mathrm{a}}$ & $0.78 \pm 0.13^{\mathrm{a}}$ & $0.88 \pm 0.04^{\mathrm{a}}$ & $1.98 \pm 0.29^{\mathrm{a}}$ & $2.62 \pm 0.08^{\mathrm{a}}$ & $3.80 \pm 0.34^{\mathrm{a}}$ & $5.00 \pm 0.25^{\mathrm{a}}$ & $2.80 \pm 0.10^{\mathrm{a}}$ & $3.22 \pm 0.06^{\mathrm{a}}$ \\
\hline
\end{tabular}

Table 2. Proximate composition ( $\mathrm{g} / 100 \mathrm{~g})$ of adult male cockroaches (Periplaneta americana) from the three locations.*

\begin{tabular}{|c|c|c|c|c|c|c|}
\hline Location & Moisture content & Fat content & Ash content & Crude fibre content & Crude protein content & Carbohydrate content \\
\hline Dumpsite & $69.91 \pm 1.29^{\mathrm{a}}$ & $6.92 \pm 1.30^{\mathrm{b}}$ & $4.16 \pm 0.23^{b}$ & $2.56 \pm 0.08^{\mathrm{b}}$ & $3.12 \pm 0.17^{\mathrm{b}}$ & $13.33 \pm 0.47^{b}$ \\
\hline Kitchen & $57.62 \pm 2.83^{b}$ & $9.96 \pm 1.41^{\mathrm{a}}$ & $6.84 \pm 1.19^{\mathrm{a}}$ & $3.81 \pm 1.13^{\mathrm{a}}$ & $4.58 \pm 0.71^{\mathrm{a}}$ & $17.19 \pm 2.83^{\mathrm{a}}$ \\
\hline Toilet & $66.60 \pm 4.24^{\mathrm{a}}$ & $7.85 \pm 1.20^{\mathrm{b}}$ & $4.98 \pm 1.39^{\mathrm{b}}$ & $2.81 \pm 0.01^{\mathrm{b}}$ & $3.56 \pm 0.08^{\mathrm{b}}$ & $14.20 \pm 1.41^{\mathrm{b}}$ \\
\hline
\end{tabular}

Table 3. Mineral composition (mg/100g) of adult male cockroaches (Periplaneta americana) from the three locations.*

\begin{tabular}{|c|c|c|c|c|c|c|}
\hline Location & $\mathrm{Na}^{+}$ & $\mathrm{K}^{+}$ & $\mathrm{Ca}^{2+}$ & $\mathrm{Mg}^{2+}$ & $\mathrm{Fe}^{2+}$ & $\mathrm{Cl}^{-}$ \\
\hline Dumpsite & $108.67 \pm 5.66^{c}$ & $241.48 \pm 1.41^{\mathrm{b}}$ & $582.02 \pm 2.85^{\mathrm{c}}$ & $496.70 \pm 10.42^{\mathrm{a}}$ & $4.52 \pm 0.72^{\mathrm{c}}$ & $6.92 \pm 1.41^{\mathrm{b}}$ \\
\hline Kitchen & $122.67 \pm 2.83^{\mathrm{a}}$ & $268.91 \pm 2.83^{\mathrm{a}}$ & $616.76 \pm 22.63^{a}$ & $518.91 \pm 13.74^{a}$ & $8.93 \pm 1.30^{\mathrm{a}}$ & $9.45 \pm 0.64^{\mathrm{a}}$ \\
\hline Toilet & $116.78 \pm 4.24^{\mathrm{b}}$ & $261.33 \pm 5.66^{\mathrm{a}}$ & $601.45 \pm 2.05^{\mathrm{b}}$ & $512.08 \pm 16.97^{\mathrm{a}}$ & $6.93 \pm 0.04^{b}$ & $7.08 \pm 0.11^{\mathrm{b}}$ \\
\hline
\end{tabular}

Table 4. Vitamins composition $(\mu / 100 \mathrm{~g})$ of adult male cockroaches (Periplaneta americana) from the three locations.*

\begin{tabular}{lccc}
\hline Location & Vitamin A & Vitamin B & Vitamin C \\
\hline Dumpsite & $362.16 \pm 2.83^{\mathrm{c}}$ & $0.45 \pm 0.00^{\mathrm{b}}$ & $4.16 \pm 0.23^{\mathrm{b}}$ \\
Kitchen & $692.83 \pm 2.87^{\mathrm{a}}$ & $0.73 \pm 0.00^{\mathrm{a}}$ & $6.23 \pm 0.31^{\mathrm{a}}$ \\
Toilet & $451.75 \pm 7.07^{\mathrm{b}}$ & $0.54 \pm 0.01^{\mathrm{b}}$ & $4.79 \pm 0.99^{\mathrm{b}}$ \\
\hline
\end{tabular}

* abc Mean ( \pm Standard deviation) values in the same column having similar superscripts are not significantly different at $\mathrm{p}>0.05$

Table 5. Distribution of microbiota from the gut of adult male cockroaches from the three locations.

\begin{tabular}{lcc}
\hline Location & Bacteria & Fungi \\
\hline Dumpsite & Staphylococcus aureus, Bacillus subtilis & Curvularia species, Geotricum species, yeast \\
Kitchen & Bacillus subtilis & Trichophton species, Curvularia species, Aspergillus candidus \\
Toilet & Enterobacter species, Bacillus subtilis & Geotricum species, Aspergillus candidus \\
\hline
\end{tabular}


microorganism in cockroaches.

This study has revealed that cockroaches are in rich vitamins $\mathrm{A}, \mathrm{B}$ and $\mathrm{C}$. Insects contain a variety of water soluble or lipophilic vitamins (FINKE 2002, Finke 2004, XiaOming et al. 2010, OonincX et al. 2012). Cockroaches from the kitchen are very rich in vitamin $C$ this could be due to the types of food they get to feed on in the kitchen area which includes cereals, fruits these foods are found in the kitchen as remnants and food spills. Dumpsite had lowest concentration of vitamin A because sources of vitamin A include palm oil, fish, egg, green vegetables, tomato and these types of food are hardly present at the dumpsite.

\section{Conclusion}

This study showed that location had an effect on the nutritional value of cockroaches.

Cockroaches found in the dumpsite and toilets have higher microbial load and less nutritional values while cockroaches in the kitchen had more nutrients and vitamins and less microbes.

This indicates that cockroaches found in the kitchen can be added to animal feeds and can also be consumed by humans.

\section{Bibliography}

Ademolu K.O and Idowu A.B (2011) Occurrence and distribution of microflora in the gut regions of variegated Grasshopper Zonocerus variegatus (Orthoptera: Pyrgomorphidae) during development. Zoological Studies 50(4): 409-415. Published by Biodiversity Research Centre, Academia Sinica, Taiwan. Available online at http:/zool stud.sinica.edu.tw

A.O.A.C (1990) Association of Official Analytical Chemists. E. W. Horwitz 13th edition Washington, D.C. $114 \mathrm{pp}$.

Barroso F.G., de Haro C., Sánchez-Muros M.J., Venegas E., MartíneZ-SÁnchez A. and PÉreZBAÑónC C. (2014) The potential of various insect species for use as food for fish. Aquaculture 422-423, 193-201.

BRENNER R.J. (1995) Economics and medical importance of German cockroaches. Understanding and controlling the German cockroach. Oxford University Press, New York, 77-92.

Brown A.E., France R.M. and Grossman S.H. (2004) Purification and characterization of arginine kinase from the American cockroach (Periplaneta americana). Archives of Insect Biochemistry and physiology 56(2): 51-60.
Etim S.E., OKon O.E., AKpan P.A., Ukpong G.I. and OKU E.E. (2013) Prevalence of cockroaches (Periplaneta amaericana) in household in Calabar. Public health implications. Journal of Public Health and Epidemiology 5(3): 149-152.

FINKE M.D. (2002) Complete nutrient composition of commercially raised invertebrates used as food for insectivores. Zoology Biology 21: 269-285.

FINKE M.D. (2004) Nutrient content of insects. In: Capinera J.L. (Ed.) Encyclopedia of Entomology, Kluwer Academic, Dordrecht, London, pp. 1562-1575.

Fischer O.A., Matlova L., DvorsKa L., Svastova P. and PAVLIK I. (2003) Nymphs of the Oriental cockroach (Blatta orientalis) as passive vectors of causal agents of avian tuberculosis and paratuberculosis. Medical and Veterinary Entomology 17: 145-150.

Huis van A., Itterbeeck van J., Klunder H., Mertens E., Halloran A., Muir G. and Vantomme P. (2013) Edible Insects. Future Prospects for Food and Feed Security, FAO, Rome, 201 pp.

IYEH C.I. (2008) Physiological studies on the daily activities of American cockroaches, Periplaneta americana. M.Sc. Thesis of Federal University of Agriculture, Abeokuta, Nigeria. 56-60.

OMUDU E.A. and EYUMAH A.O. (2008) A study of cockroach (Dictyoptera: Blatidae) infestation in different types of residential buildings in Markurdi Nigeria. Nigerian Journal of Entomology 25: 11-17.

Oonincx D.G.A.B. and DiERENFELD E.S. (2012) An investigation into the chemical composition of alternative invertebrate prey. Zoology Biology 31: 4054.

Payne C.L.R., Scarborough P., Rayner M. and Nonaka K. (2016) Are edible insects more or less 'healthy' than commonly consumed meats? A comparison using two nutrient profiling models developed to combat over and under nutrition. European Journal of Clinical Nutrition 70: 285-291.

Richards A.G. and BRooks M.A. (1958) Internal symbiosis in insects. Annual Review of Entomology 3: 37-56.

Sneath P.H.A., Mair N.S, Sharpe M.E., Holt J.G. (1986) Bergey's manual of systematic bacteriology. Vol. 2. Baltimore, MD: Williams and Wilkins.

UÇKay I., SAX H., Di Pietro S.L., Baur H., Boulc'H M., Akakpo C., Chevrolet J. and Pittet D. (2009) Cockroaches (Ectobius vittiventris) in an intensive care unit, Switzerland. In: William J.B., LouIs M.R., and Christine A.M. (2011) Cockroaches: Ecology, behavior and natural history. All pest roaches review 248: $125-142$.

YI L., LaKemond C.M.M., SAgIS L.M.C., EISNERSchadler V., van Huis A., and van BoeKel M.A.J.S. (2013) Extraction and characterization of protein fractions from five insect species. Journal of Food Chemistry 141: 3341-3348.
Kehinde Olutoyin Ademolu Department of Pure and Applied Zoology, Federal University of Agriculture, Abeokuta, Nigeria E-mail:kennyademolu@yahoo.com
Oluwatosin Yetunde MustaPHA Department of Pure and Applied Zoology, Federal University of Agriculture, Abeokuta, Nigeria E-mail: tosinmustapha2013@gmail.com
Adewunmi Babatunde IDowu Department of Pure and Applied Zoology, Federal University of Agriculture, Abeokuta, Nigeria E-mail:tomiwo2@yahoo.com 